\title{
Determination of phases and residual stresses after martensitic transformation induced by rolling in $304 \mathrm{~L}$ stainless steel
}

\author{
Deteminação de fases e tensão residual após \\ transformação martensítica induzida por \\ laminação em aço inoxidável 304L
}

Juciane Maria Alves ${ }^{1,2}$, Luiz Paulo Brandao ${ }^{1}$, Andersan dos Santos Paula ${ }^{1}$

\footnotetext{
${ }^{1}$ Military Institute Engineering, Materials Engineering Section, Postgraduate Program in Materials Science, Rio de Janeiro, Rio de Janeiro, Brazil.

${ }^{2}$ Brazilian Center for Research in Physics, Laboratory of Applied Magnetism, Rio de Janeiro, Rio de Janeiro, Brazil. e-mail: juciane_alves_rj@yahoo.com.br, brandao@ime.eb.br, andersan@ime.eb.br
}

\begin{abstract}
The 304L austenitic stainless steel is susceptible to deformation induced martensitic transformation. This phase transformation depends on the temperature as well as on the mode, rate and level of deformation. In this work the phases and residual stresses of a 304L TRIP steel where martensitic transformation was induced by cold rolling were investigated by X-ray diffraction XRD. The analyses were performed for different sample thicknesses. The results showed that the phase composition and the residual stresses are strongly dependent on sample thickness. All samples showed a compressive residual stress.
\end{abstract}

Keywords: 304L Stainless Steel, Martensitic Transformation, Residual Stress, Thickness variation.

\section{RESUMO}

O aço inoxidável austenítico 304L é suscetível à transformação martensítica induzida por deformação. Esta transformação de fases depende da temperatura, assim como do modo, taxa e nível de deformação. Neste trabalho as fases e tensões residuais de um aço TRIP 304L, em que a transformação martensítica foi induzida por laminação a frio, foram investigadas por difração de raios-X (DRX). As análises foram realizadas em diferentes espessuras das amostras. Os resultados mostraram que a composição de fases e as tensões residuais são fortemente dependentes da espessura das amostras. Todas as amostras apresentaram tensão residual compressiva.

Palavras-chave: Aço Inoxidável 304L, Transformação Martensítica, Tensão Residual, Variação de Espessura.

\section{INTRODUCTION}

The transformation induced plasticity (TRIP) may occur in a wide temperature range an depends on several other parameters, such as the chemical composition of the alloy and the mode, rate and level of deformation. The products of the phase transformation austenite-martensite, in TRIP steel may be $\varepsilon$ and $\alpha^{\prime}$ martensite. The $\varepsilon$-martensite nucleation occurs in the stacking faults intersections and $\alpha^{\prime}$-martensite nucleation arises in $\varepsilon$ martensite and the intersections among shear bands [1-3].

The chemical composition of the alloy influences important intrinsic features of phase transformation such as stacking fault energy (SFE), martensite formation starting temperature $\left(\mathrm{M}_{\mathrm{s}}\right)$ and $\mathrm{M}_{\mathrm{d} 30}$ temperature. The $\mathrm{M}_{\mathrm{d} 30}$ is the temperature where $30 \%$ of the strain induces $50 \%$ martensitic formation [4-6]. A lower percentage of alloying elements increases the austenite instability. Thus, the lower the number of elements in a TRIP steel and the lower the temperature during the deformation process, more intensity martensitic transformation [7]. The residual stress fields near dislocations influence the nucleation of martensite. Thus, the austenite-martensite transformation may occur heterogeneously [8]. 
Residual stresses are those that remain in a sample in the absence of external loads or temperature gradients. The residual stresses induced by austenite-martensite phase transformation arise mainly by volume expansion, elastic incompatibility and plastic mismatch between austenite and martensite [9]. The deformation induced martensitic transformation promotes local deformation fields causing stress variations in both austenite and martensite phases [9]. In general, the residual stresses are consequences of interactions between deformation, temperature and microstructure [9].

The purpose of the present work was to investigate the effect of the amount of thickness reduction on the properties of martensite induced by rolling in the 304L austenitic steel is article results showed that the residual stress and quantitively phase analysis of the martensitic transformation evolved as a function of rolling reductions. There was variation martensite content and residual stress gradient in analyzes performed in different sample thicknesses. A compressive residual stress state was observed for all samples sections thicknesses.

\section{MATERIALS AND METHODS}

The material under study consisted in 304L austenitic stainless-steel sheets, received in the condition of hot rolling, with a thickness of $6.37 \mathrm{~mm}$. The chemical composition of the alloy is shown in Table 1 .

Table 1: Chemical composition of 304L stainless steel (weight \%).

\begin{tabular}{c|c|c|c|c|c|c}
\hline $\mathbf{C}$ & $\mathbf{M n}$ & $\mathbf{S i}$ & $\mathbf{C r}$ & $\mathbf{N i}$ & $\mathbf{M o}$ & $\mathbf{N}$ \\
\hline 0.0196 & 1.262 & 0.491 & 18.036 & 8.084 & 0.135 & 0.051 \\
\hline
\end{tabular}

The martensitic transformation was induced by rolling at room temperature $\left(25{ }^{\circ} \mathrm{C}\right)$ with $20 \%$ and $80 \%$ reductions. For $20 \%$ reduction, 2 passes were used, and for $80 \%$ reduction, 15 passes were used, with approximately $10 \%$ reduction per pass. The deformation average rate was $9.8 \times 10 \mathrm{~s}^{-1}( \pm 1.6)$.

After rolling, the material was cut into samples with an area of $20 \times 20 \mathrm{~mm}$. The samples were ground with grit sizes of 200, 400, 600, 800 and 1200 mesh. Then, electrolytic polishing using a solution of 20\% perchloric acid in ethanol. Only the front surface of the sample was placed in contact with the electrolytic solution; an electrical tape was used to cover the sides and the back surface of the sample, since it was observed that these areas, when exposed, decreased the etching speed.

The phase analyses were performed by XRD using a PANalytical X'PERT PRO MRD diffractometer. The measurement parameters were initial and final angles of 45 and $130^{\circ}$, step size of $0.030^{\circ}$ and time per step of $200 \mathrm{~s}$. The peaks associated with austenite and martensite were analyzed using ICDD crystallographic data ( $\gamma$-phase 00-047-1417 and $\alpha^{\prime}$-phase 03-065-7753).

The residual stress measurements were performed by the psi geometry method with multidirectional analysis, using several tilt angles in psi $(\psi)$ such as $26.95,39.86,51.71,65.00,0.00,26.95,39.86,51.71$ and $65.00^{\circ}$ and, for each psi, phi $(\varphi)$ rotations of 0,45 and $90^{\circ}$. Thus, each measurement was produced through 27 scans resulting from a combination of 9 tilts in psi with 3 directions in phi for each value of psi (Figure 1). These points were used to determine, with good accuracy, the interplanar distance versus $\operatorname{sen}^{2} \psi$ graph shown in Figure 2.

Residual stress measurement and phase analysis for austenite and martensite were performed for the sample surface and when the sample thickness was reduced to $1 / 4$ and $1 / 2$ the initial thickness using mechanical grinding. 


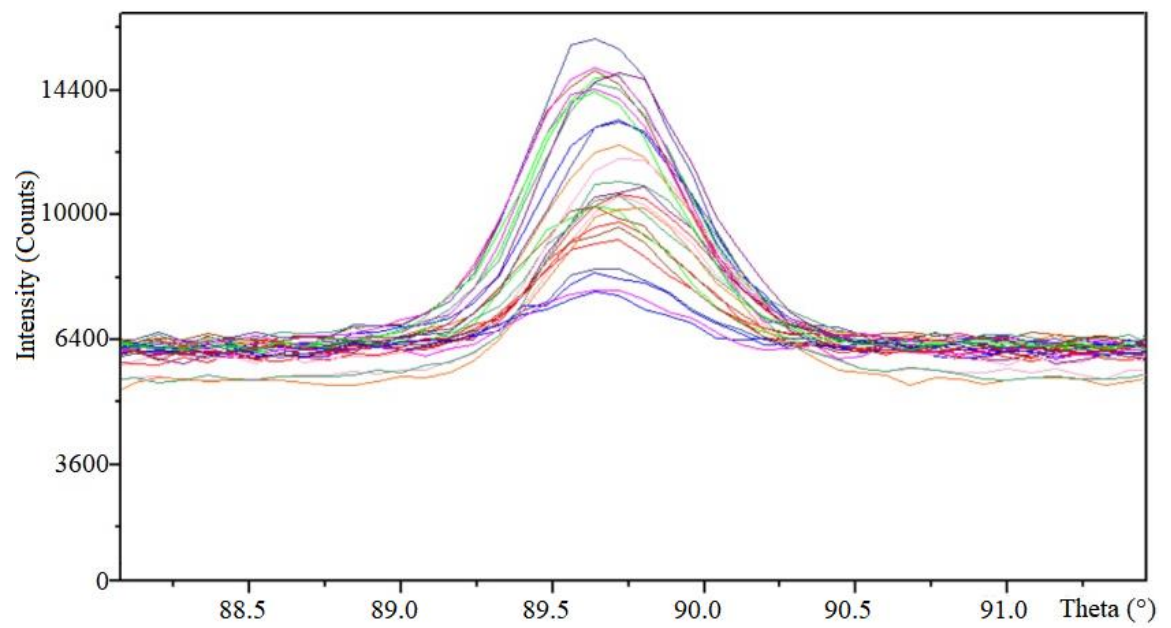

Figure 1: Multidirectional analysis of residual stress by XRD (27 scans).

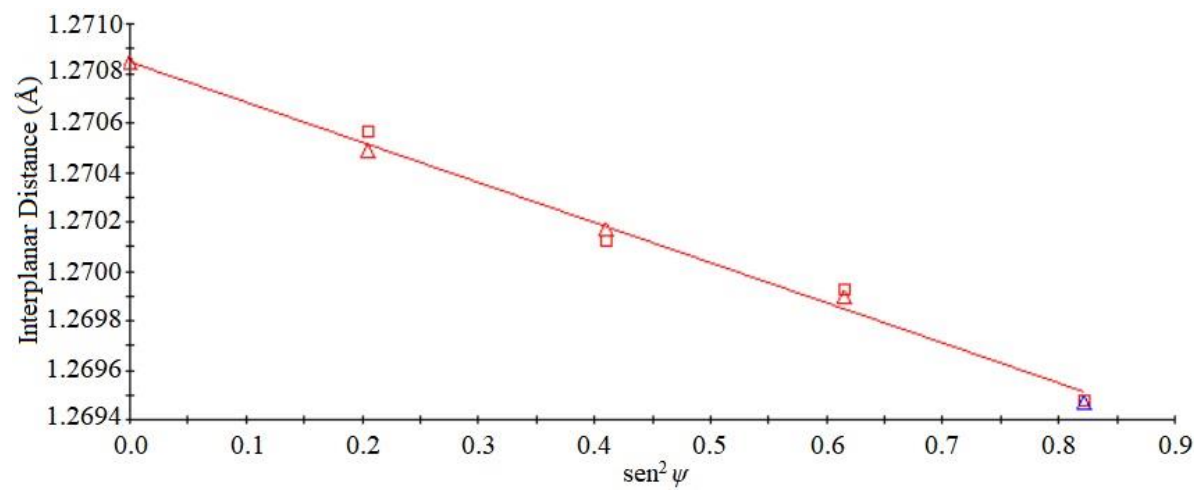

Figure 2: Interplanar distance versus $\operatorname{sen}^{2} \psi$. Squares refer to measurements for psi angles positive and the triangles to the measurements for negative psi angles.

\section{RESULTS AND DISCUSSION}

The diffractograms showed that as the sample thickness was reduced by rolling, the intensity of austenite peaks decreased and the intensity of the martensite peaks increased. The diffraction peaks associated with austenite and martensite were, respectively, $\gamma$ [(111), (200), (220), (311), (222)] and $\alpha^{\prime}[(110),(200),(211)]$, as shown in Figure 3. 


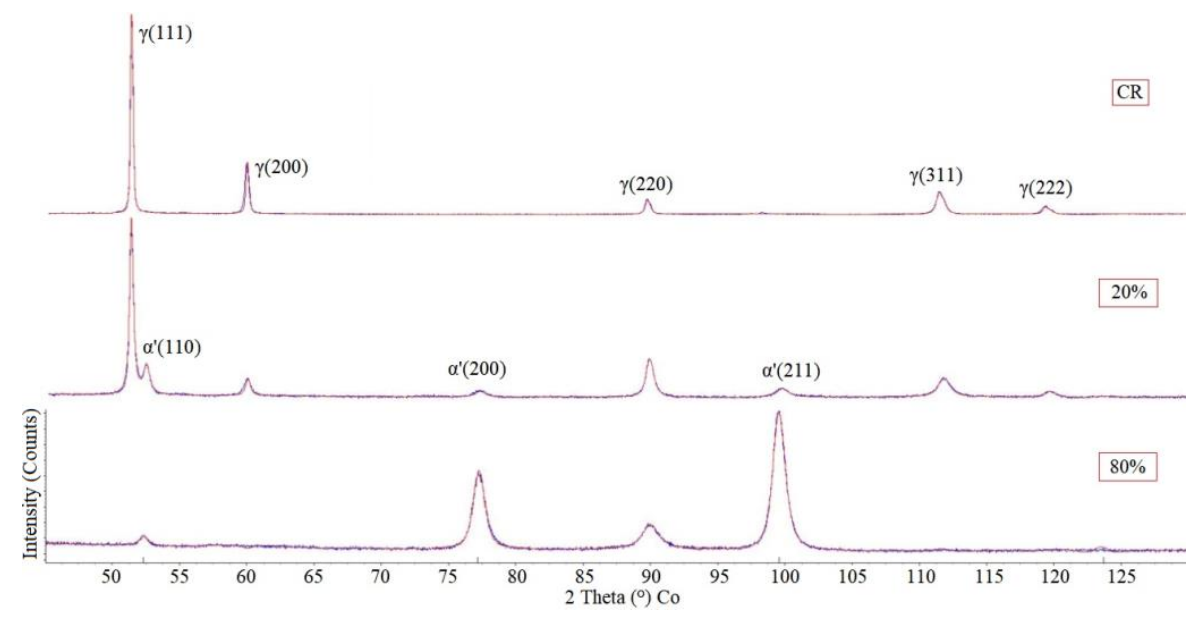

Figure 3: XRD of rolled samples at room temperature with 20 and $80 \%$ reduction.

The quantitative results, obtained by the Rietveld method, showed $35 \%$ martensite for $20 \%$ of rolling reduction and $96 \%$ martensite phase for $80 \%$ reduction. The volume fraction of martensite was different at the surface and when the sample thickness was reduced to $1 / 4$ and $1 / 2$ the initial thickness (Table 2). This is probably due to the heterogeneity of martensite nucleation, as reported by FISHER [8]. It was observed that martensite volumetric variation in sample with $20 \%$ reduction in thickness was not very significant for the analyzes performed between sample surface and the $1 / 4$ thickness (35 and 32\% martensite), respectively, but they were meaningful on the comparison to the $24 \%$ of volume fraction observed on $1 / 2$ thickness.

The analysis of the sample with $80 \%$ thickness reduction showed $96 \%$ martensite on surface and $88 \%$ and $79 \%$ on $1 / 4$ and $1 / 2$ thickness, respectively. The sample as received (AS) showed no significant martensite variation between plane and half thickness, a martensite percentage obtained was 0.8 and $0.9 \%$, respectively, close to the technique detection limit (Table 2).

Residual stress measurements of austenite and martensite were performed as well. For the sample as received and for a $20 \%$ reduction, the volume fraction of martensite is so low that the measurement is assumed to be the residual stress of austenite. For the sample with $80 \%$ reduction, the volume fraction of austenite is so low that the measurement is assumed to be the residual stress of martensite (Table 2).

Table 2: Phases and residual stress quantification after martenstític transformation of 304L stainless steel.

\begin{tabular}{c|c|c|c}
\hline SAMPLE & VOLUME $\boldsymbol{\alpha}^{\prime}(\mathbf{V} \%)$ & RESIDUAL STRESS $\mathbf{Y}(\mathbf{M P a})$ & STANDARD DEVIATION (MPa) \\
\hline AR_Surface & 0.8 & -184 & 8 \\
\hline AR_1/4 & 0.8 & -153 & 17 \\
\hline AR_1/2 & 0.9 & -98 & 23 \\
\hline SAMPLE & VOLUME $\boldsymbol{\alpha}^{\prime}(\mathbf{V} \%)$ & RESIDUAL STRESS $\mathbf{Y}(\mathbf{M P a})$ & STANDARD DEVIATION (MPa) \\
\hline $20 \_$Surface & 35 & -50 & 22 \\
\hline $20 \_1 / 4$ & 32 & -78 & 23 \\
\hline $20 \_1 / 2$ & 24 & -113 & 50 \\
\hline SAMPLE & VOLUME $\boldsymbol{\alpha}^{\prime}(\mathbf{V} \%)$ & RESIDUAL STRESS Y(MPa) & STANDARD DEVIATION (MPa) \\
\hline $80 \_$Surface & 96 & -180 & 55 \\
\hline $80 \_1 / 4$ & 88 & -184 & 59 \\
\hline $80 \_1 / 2$ & 79 & -209 &
\end{tabular}

The residual stress analyses show a compressive stress gradient from the surface to half thickness. The sample as received had a larger residual stress at the surface, while those with 20 and $80 \%$ reduction had a larger compressive stress at half thickness. The residual stress of the as received sample is attributed to the previous thermomechanical processing, hot rolling.

In the case of samples submitted to martensitic transformation induction by rolling, with 20 and $80 \%$ reductions, a larger compressive residual stress was observed at half thickness. The largest stress (-209 MPa) was observed in sample with highest reduction, $80 \%$, and, consequently, the largest volume fraction of martensite. The residual stresses in rolled samples are due consequences to phase transformation and of the 
interaction between stresses arising phase change with those promoted material plastic deformation in the rolling process. It is difficult to separate the two contributions, since the phase transformation occurred by plastic deformation.

\section{CONCLUSION}

The present results show that martensitic transformation can be achieved by cold rolling in 304L stainless steel. There was a gradient of the volume fraction of martensite from the surface to half sample thickness. There was also a gradient of compressive residual stress from the surface to half sample thickness. The residual stresses are attributed the interaction between phase transformation and plastic deformation in the rolling process.

\section{ACKNOWLEDGMENTS}

The authors thank Aperam South America for supplying the material, FAPERJ for a Doctorate scholarship and CNPq for a research productivity grant (PQ-2), process 307798 / 2015-1.

\section{BIBLIOGRAPHY}

[1] TALONEN, J., HANNINEN H, "Formation of Shear Bands and Strain-Induced Martensite During Plastic Deformation of Metastable Austenitic Stainless Steels", Acta Materialia, v. 55, pp. 6108-6118, 2007.

[2] SHEN, Y.S., LI, X.X., SUN, X., et al., "Twinning and Martensite in A 304 Austenitic Stainless Steel", Materials Science and Engineering A, v. 552, pp. 514-522, 2012.

[3] OKAYASU, M., TOMIDA, S., "Phase Transformation System of Austenitic Stainless Steels Obtained by Permanent Compressive Strain", Materials Science and Engineering A, v. 684, pp. 712-725, 2017.

[4] CINA, B., "Effect of Cold Work on the Gamma-Alpha Transformation in Some Fe-Ni-Cr Alloys", Journal of the Iron and Steel Institute, v. 177, pp. 406-422, 1954.

[5] ANGEL, T., "Formation of Martensite in Austenitic Steels", Journal of the Iron and Steel Institute, v. 177, pp. 165-174, 1954.

[6] HEDAYATI, A., NAJAFIZADEH, A., KERMANPUR, A. et al., "The Effect of Cold Rolling Regime on Microstructure and Mechanical Properties of AISI 304L Stainless Steel", Journal of Materials Processing Technology, v. 210, pp. 1017-1022, 2010.

[7] ANTUNES, A.E.B., ANTUNES, L.M.D., SAMPAIO, M., "Comportamento Plástico no Escoamento de Aços Inoxidáveis Austeníticos Metaestáveis", Revista Brasileira de Aplicações de Vácuo, v. 30 n.1-2, pp. 1823, 2011.

[8] FISHER, J.C., TURNBULL, D., "Influence of Stress on Martensite Nucleation", Acta Metallurgica, v. 1, v.5, pp. 310-314, 1953.

[9] PAPUlA, S., TALONEN, J., HANNINEN, H., "Effect of Residual Stress and Strain-Induced A'Martensite on Delayed Cracking of Metastable Austenitic Stainless Steels", Metallurgical and Materials Transactions, v. 45a, pp. 1238-1246, 2014.

\section{ORCID}

Juciane Maria Alves

https://orcid.org/0000-0001-7433-8838

Luiz Paulo Brandao https://orcid.org/0000-0002-2623-648X

Andersan dos Santos Paula

https://orcid.org/0000-0002-0904-4240 